\title{
螢光ガラス線量計による測定における誤差の検討
}

\author{
大阪市立大学医学部放射線医学教室 \\ 光田秀 雄
}

（論文受付 炤和 42 年 4 月 11 日）

\section{STUDY ON ERROR IN MEASUREMENT WITH \\ FLUORO GLASS DOSIMETER}

\author{
By Hideo MitsuTA \\ Dept. of Radiology Osaka City University \\ Medical School
}

(Article received : April, 11, 1967)

\section{Summary}

The author studied an error of numerical value in measurement with fluoro glass dosimeter. The fluoro glass dosimeter. The fluoro glass used in this study was FD-R1-1 (Toshiba) and had a diameter of $1 \mathrm{~mm}$ and a length of $6 \mathrm{~mm}$. The fluorh meter was FGD-3B (Toshiba).

The author applied electron beam of Betatron to the fluoro glass dosimeter in a phantom made of acrylite.

The fluctuation of the numerical value of the fluoro meter in a short time was about $\pm 0.15 \mathrm{R}$; the error of the numerical value, which was probably due to the play of the apparatus, was about $1.56 \%$. The response of the fluoro glass showed a good linearity, extending $1-10^{3} \mathrm{R}$ of the fluorescence; the fluorescence of the back ground of the fluoro glass was about $0.7 \pm 0.07 \mathrm{R}(\overline{\mathrm{O}} / \overline{\mathrm{x}}=10 \%)$. In this experiment, the author studied also the response of the fluoro glass, using about 100 fluoro glasses. The result was as follows;

Fluorescence

The standard deviation in the response

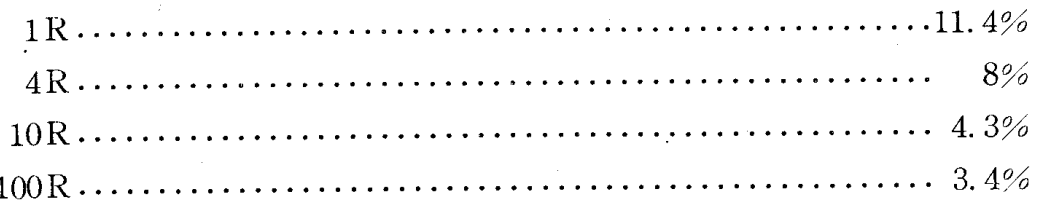

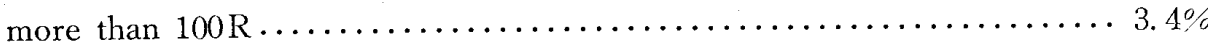

It may be said through the comparative study over foreign literature that these numerical value showed better efficiency of this fluoro glass dosimeter the that of foreign ones.

The fading of the fluorescence reaches to $5 \%$ in 100days and the value of the fading is apot to be divided. The fading is caused also by repeating the measurement of the fluorescence.

The author made a futher examination on the error in the measurement with fluoro glass dosimeter through these results mentioned above and other literatures.

\section{I. 緒 言}

监光ガラス線量計の特長，忍归についてはすでに多く の報告があるが，本研究は笔光ガラス線量計による測定
值の䛊差について検馀することを目的としたすのである。 研究対象とした监光ガラスは放射線治燃に関する测定に 最も多く利肘されている $1 \mathrm{~mm} \phi \times 6 \mathrm{~mm}$ の円柱形のもの である。 


\section{II. 実験対象, 使用測定器など}

\section{1. 蛍光ガラス}

本研究に用いた蛍光ガラスは東芝製 FD-R1-1. その 大きさは直径 $1 \mathrm{~mm}$, 長さ $6 \mathrm{~mm}$ 円柱形で, 組成は $\mathrm{Al}$ $\left(\mathrm{PO}_{3}\right)_{3}-50, \mathrm{LiPO}_{3}-50$ のガラス基材に $\mathrm{AgPO}_{3} 8 \%, \mathrm{~B}_{2} \mathrm{O}_{3}$ $3 \%$ (重量\%)を導入したもので柬芝中央研究所横田研究 室で開発されたむのである122)。乙のガラスは一般に Low-Z type または Li ガラスとよばれる種類に属し, これに対して Schulman らの開発した High-Z type ま たは $\mathrm{Ba}$ ガラスとよばれるものは, $\mathrm{Al}\left(\mathrm{PO}_{3}\right)_{3}-50, \mathrm{KPO}_{3}$ $-25, \mathrm{Ba}\left(\mathrm{PO}_{3}\right)_{2}-25$ のガラスに $8 \%$ の $\mathrm{AgPO}_{3}$ を加えたむ のである. その back ground の大きさ，感度などの上

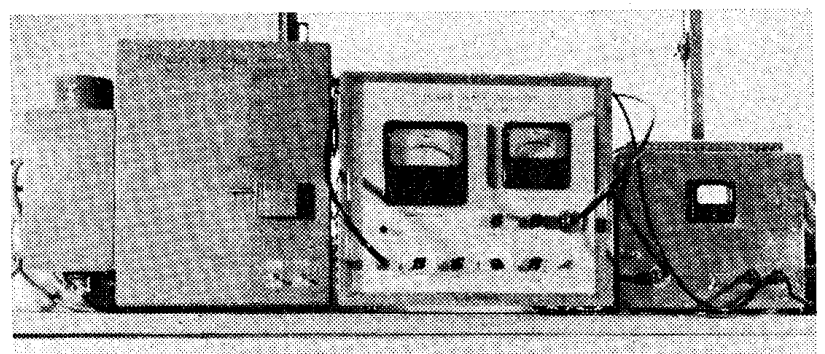

Fig. 1. Fluoro glass dosimeter FGD-3B (Toshiba).

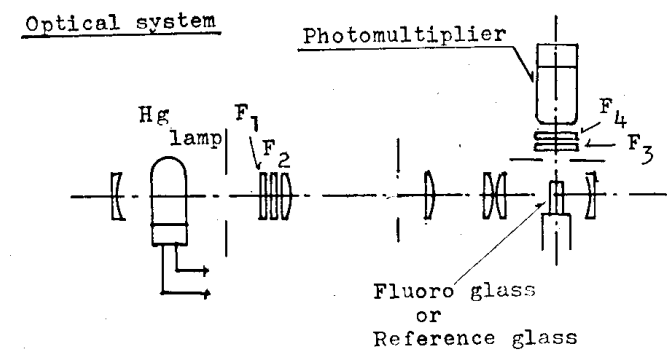

Electronic circuit

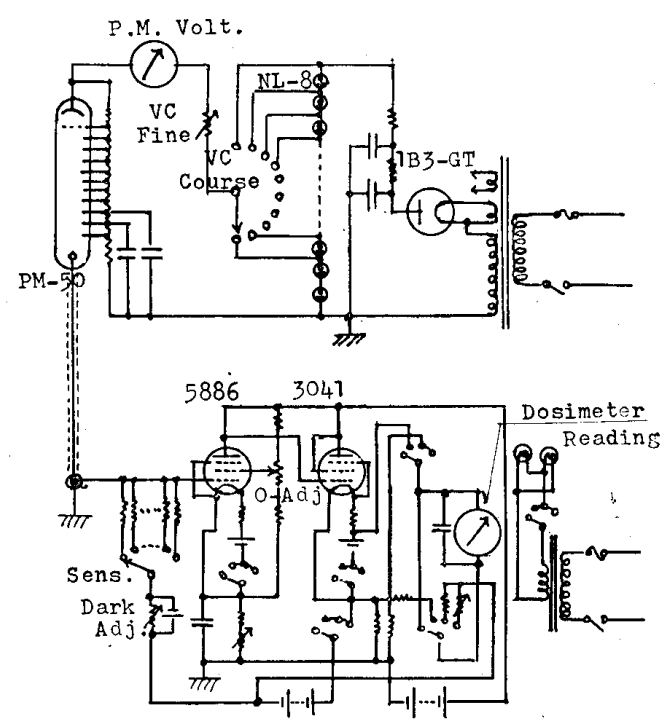

Fig. 2. Fluoro glass dosimeter FGD-3B (Toshiba).
から横田ガラスが優れているととは Cheka 始めいくつ

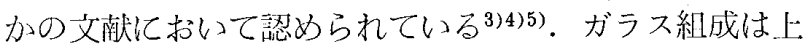
記の他数種のものが開発されている(2)36).

\section{2. 蛍光量計}

東芝製 FGD-3B を用いた。外観はFig. 1，構造はFig. 2のようであって，蛍光ガラスを照合ガラス (reference glass）之称する安定した標準の监光を発するガラスと適 時置き換えて监光量計の感度変化を check し，補正する ようになっている7)。米国 Bausch \& Lomb 社の microdosimeter readerは监光励起紫外線の光路を二つに分け, 一方を监光ガラスに入射し蛍光を光電子増倍管で受け, 一方を他の光電子增倍管に入れてその二つの出力を差動 增幅器に入れて一定感度を保つようにしているが8)，乙 の方式では 2 本の光電子增倍管の性能（特に drift）を揃 えるととが難しく，やや操作が煩雑ではあるが東芝の方 式が正確度は高いといわれている，また FGD-3Bでは 励起紫外線はガラスの側面（円柱側面）より照射され， 蛍光はこれ之直角の方向（円柱底面の方向）から測定す る方式であるが，前述の B.L. 社のむのは円柱底面より 豞起紫外線在入射し, その反対側底面から蛍光測定を行 なうために巣光中に紫外線が混入し, back ground を増 す結果となっている。

本蛍光量計の出力は, 光電流增幅回路の出力電流値 ( $\mu \mathrm{A})$ として目盛られており, 前述の照合ガラスの標準 蛍光加ら ${ }^{60} \mathrm{Cor}$ 線の exposure 值 $(\mathrm{R})$ 亿換算するように なっているが, 著者は照合ガラスの登光を感度設定のた めの一つの標準としてのみ用い, exposure または dose に換算するには同一エネルギによる標準照射をした爯光 ガラスによる較正図を用いるようにしている。感度レン ジの切換は二つの knob (BATT. および SENS) によっ て訪器指示值の $\times 1 / 10$ から $\times 1,000$ までの 9 段が選択でき る. 出力指示電流計物精度は 1.0 級, 光霄子増倍管印加 電圧指示蕓圧計は1.5級である。

\section{3. 照射放射繶および照射方法}

医用 $15 \mathrm{MeV}$ ベータトロン（東芝 BMR-15）による 15 $\mathrm{MeV}$ 䨤子線（照射野 $8 \times 8 \mathrm{~cm}$ ) を用い, 後述の上うにア クリル樹脂で作ったファントム中で照射した。 $15 \mathrm{MeV}$ 霄子線を用いた理由は本研究がベータトロン霆子線測定 の研究と前行して行なったむので，また容易に大線量の 照射ができるからであある。

他の chemical dosimetryによる研究に执いて，ファ ントム中に挿入した指頭電離槽による測定值 $(R)$ とdose の関係が, $15 \mathrm{MeV} \mathrm{X}$ 線 電子線, $200 \mathrm{kV} \mathrm{X}$ 線の間であま り大きい差が認められなかったし，また指頭電離槽によ 
る読みを基準とした $15 \mathrm{MeV}$ 電子線と $15 \mathrm{MeV}$ X線につ いての监光ガラスのレスポンスが殆ど同一でありまた $\mathrm{Ra}$ 針による $r$ 線に対するレスポンスもほぼ同じであっ たととなどから, 本研究による結果はX線， $r$ 線に対し ても適用できるむのと考えられる。

ただし，ベータトロン電子線（X線も）は極めて幅が 狭く波高の大なパルスとして発生するため，電離槽にお ける recombination loss と同様な factor を考虑する必 要があるかも知れない：また中，低エネルギX線に対し ては蛍光ガラスのレスポンスは著しく異なるため多少の 補正は必要であろう。

照射のためのファントムはFig. 3 のようなアクリラ トイ製ブロックで，表面より $15 \mathrm{~mm}$ 下に深さ $1 \mathrm{~mm}$, 大き

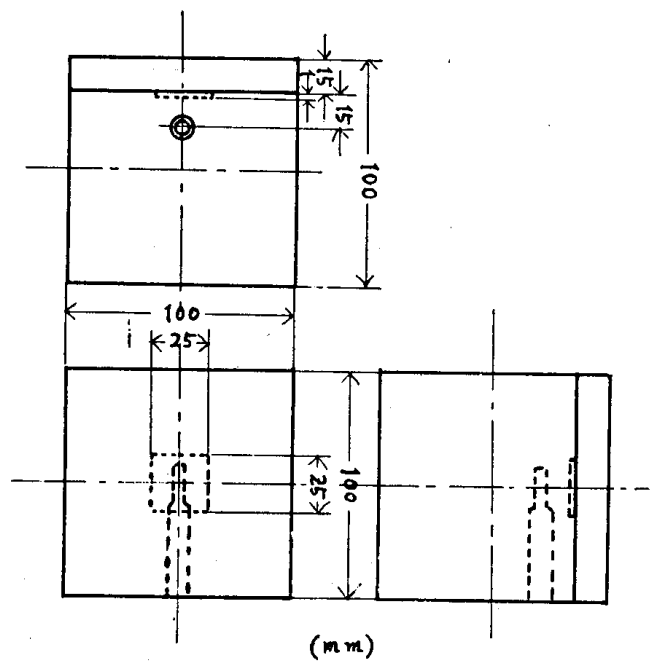

Fig. 3. Phantom used for irradiation of fluolo glass rods. (Acrylite)

さ25×25mm の空洞を作り（実際にはこの大きさの穴の 上に $15 \mathrm{~mm}$ のアクリル板を重ねる構造), 蛍光ガラスを この中に並べて入れ，空隙には水を満たす，乙れより更 に15mm 下，すなわち表面より $30 \mathrm{~mm}$ 下に指頭形電離を 挿入する。このガラスの位置 $(15 \mathrm{~mm})$ と電離槽の位置 $(30$ $\mathrm{mm})$ の線量の比は，同じ電離槽で測定した結果約100:90 であったので, 電離槽線量の読みを 1.1 倍した 值をむっ て exposure の值とし，以下 “R” の記号をむって表わ す. 前述のごとくとの值は近似的に exposure $(R)$ と一 致し，また極めて荒っぽく言って人体㳄組織において dose (rad) はほぼ exposure (R) と近似であるから，他 の文献にみられる $\mathrm{rad}$ 単位による報告も本研究結果と 比較することができる。

後述するように放射線照射時の混度による感度変化が あるため，20Cを標準とし，照射中はできるだけとれに 近い温度にするように努力した。
指頭㰷電济槽線量計としては Baldwin 製 IONEX Mk-3 thimble chamber (容棈 $0.6 \mathrm{cc}$, 壁擪 $0.6 \mathrm{~mm}$, 外 往約 $7 \mathrm{~mm}$ ) 老用いた。

\section{4. 蛍光の測定}

监光ガラス，照合ガラスおよびそれらのホルダーの励 染は大きい愦差の原因となるためそれらの洗桬には特に 注意した. 中性洗㓮一純水一純アルコールの順に, また は純アセトン一純水一純アルコールの順で洗い, 特にガ ラスに対してはその第一段階で，まず指先をアセトンで 十分洗い, ガラスをつまんで, あらかじめアャトンで洗 ったガーゼの小片によって第 1 液中で拭うようにした。

虫光量は照射終了後から徐々に増加し, 数時間でほぼ 飽和值に達するので1), 照射終了後 24 ～48 時間後に蛍光 量を測定するようにした。なお，後述するように照射後 あまり長時間経つと fading やバラツキが大きくなる。

\section{III. 実験およびその結果}

\section{1. 蛍光量計の誝差の原因}

i ）感度切換に伴う詋差

前記のように感度の選択は二つの knobによって行な

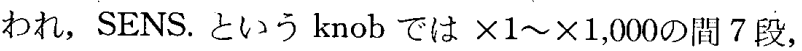
BATT.という knob は SENS. の全レンジに対して×1, ×11亿0の 2 段であるが，後者の×1/10なる位置は前者の最低 レンジである× 1 と 3 に対してのみ必要であって, 結局

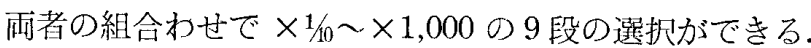

Table 1. The ellor followed selecting of sensitivity knobs ("SENS" and "BATT").

Switching of "BATT" knob :

Neglisible to all position of "SENS" knob.

Switching of "SENS" knob :

\begin{tabular}{c|c}
\hline Position of knob & Readings \\
\hline $1 / 3$ & $99 / 34$ \\
$3 / 10$ & $50 / 15.1$ \\
$1 / 3 / 10$ & $100 / 34 / 10.3$ \\
$10 / 30 / 100$ & $100 / 33.3 / 10$ \\
\hline
\end{tabular}

この全段に亘って相互間の誤差を知ることは user と しては不可能に近く，製品を信用する他ないが，近接レ ンジ間の比較をしてみた。すすねわ执方のレンジで ほぼ full scaleを示すような営光ガラスを用い次の段ま たは更に次の段の指度を比較した。 その結果は Table 1 のようであった．同表 Readings の欄は計器（ $\mu \mathrm{A}$ で日 盛られている）の読みそのものを示す，従って例えば1 とその 3 の knob の位置の比較に打いて，その值の比は 
$99: 34 \times 3=99: 102 \doteqdot 100: 103$

である。とのように隣接レンジ問で $3 \%$ という积差はや や大きすぎるようであるが，乙の実験には後に述べるよ うな他の factor 屯考えられ，必ずしも $3 \%$ の䛊差がある と断言できない。

後述の照射量対蛍光ガラスレスポンスの関係を求める 実験結果にみられるように，ある範囲でよく直線に乗つ ているととは, 逆に言って蛍光量計の指度が，少なくと むこの範囲 (最小レンジから×1,000またはそれ以上の1 ンジまで）でよい linearityを示すととを意味するとす 言える.

ii）光電子增倍管印加電圧の変動による誤差

光電子増倍管印加電圧を変化させると指示值は変化す る。約 $100 \mathrm{R}$ 照射したガラスにつき電压を変化させると 出力は Fig. 4 のように $1 \mathrm{~V}$ 当り約1\%の変動を示す. こ の值はかなり大きい数值ではあるが, 電源電圧が十分安 定化されて招り，照合ガラスによって感度変化を適時 check し補正するため，乙の点は殆んど問題とするに足 らない.

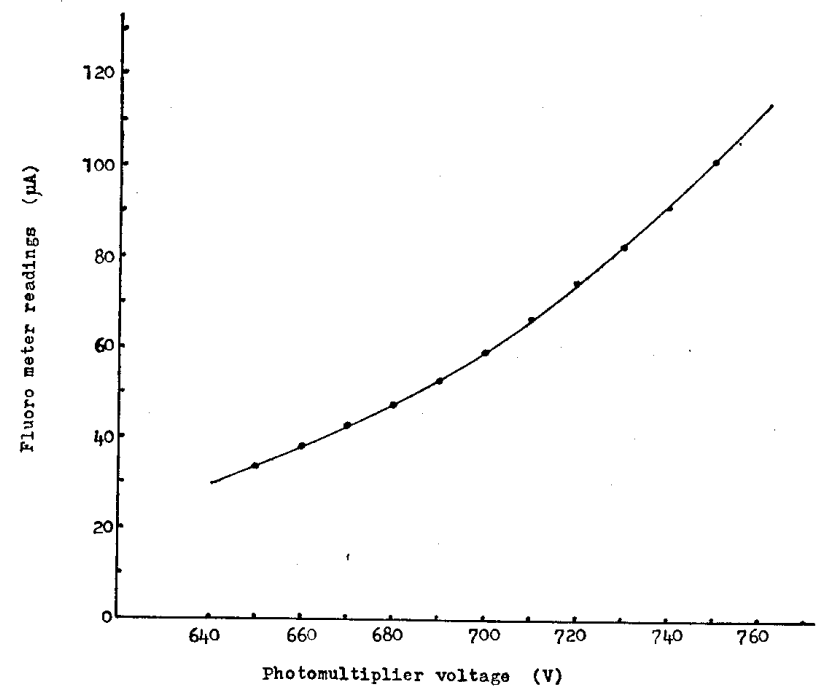

Fig. 4. A case of relationship photomultiplier voltage and fluoro-meter readings.

iii）極めて小さい入力に対する指示值のバラッキ

照合ガラスの0Rーすなわち蛍光が全く0-のものを両端 より交互に繰り返し测定した。蛍光ガラスの未照射のむ のの指示值すなわち back ground（または pre-dose）は 明らかに一種の爯光であるが， $0 R$ の照合ガラスの場合 は蛍光は全く0であって，乙の場合の蛍光量計の微小な 読みを励起紫外線の迷入によるあの上考えられる。しか しとのガラスの寸法精度が完全なむのであり，またその 洗涤が十分に行なわれているならば光電子増倍管への人

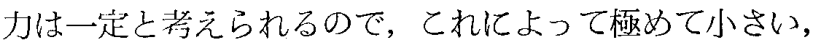
そして一定の入力について巣光量計指示のバラッキを 知ることができる. Table 2 はガラスを両端交互に15回 入れ換えて測定した結果である.乙の場合，最小レンジ

Table 2. The dispersion of fluoro-meter readings in very small input.

\begin{tabular}{c|c}
\hline Fluoro-meter readings & Times \\
\hline 0.25 & 0 \\
0.3 & 8 \\
0.35 & 5 \\
0.4 & 2 \\
0.45 & 0 \\
\hline total & 15 \\
\hline
\end{tabular}

で計器目盛の最小値, すなわち $0.1 \mu \mathrm{A}$ 以内の短時間変 動があるためその変動のほぼ中央值と思われる值と思わ れる值を読んだ。しかしとの変動は後述の実験から約 0.15 “R” であるから，実際上の測定に大きい誤差を与 えることはない。乙の測定時の指示計器（電流計）は full scale $10.0(\mu \mathrm{A})$, 最小目盛は $0.1(\mu \mathrm{A})$ である. こ の読みのバラッキは主としてガラスの setting に際して のの機械的誤差, 光電流回路の noise, 紫外線ランプの 出力のゆらぎなどによるあのと考えられる.

iv）中等度入力についての振れ

後述するように，照射済蛍光ガラスを何度す繰返して 単光測定をすると fading を生じるため照合ガラスの適 当なむの(後述の蛍光ガラスレスポンスとして約 87 “ $R$ ” 相当）を繰返し測定した．Table 3 にその結果を示す.

Table 3. The dispersion of fluoro-meter readings in medium input.

\begin{tabular}{c|c}
\hline Fluoro-meter readings & Times \\
\hline 60.5 & 0 \\
61 & 1 \\
61.5 & 3 \\
62 & 6 \\
62.5 & 1 \\
63 & 5 \\
63.5 & 7 \\
64 & 5 \\
64.5 & 2 \\
65 & 0 \\
\hline total & 30 \\
\hline
\end{tabular}

Mean : 62.95

Standard deviation : $0.983=1.56 \%$ 
照合ガラスの等光能は一定であるから，この涟のバラッ キはガラスの mispositioning, 鉴光量計回路の短时得感 度変化, 紫外線ランプの出力変動など监光量計そのすの による愦差と考えられる。

Table 3 にみられるようにその標準偏差は $1.56 \%$ あ゙ る.

\section{2. 照射量対蛍光量の直線性}

䛊差を云々するために蛍光ガラスのレスポンスを求め ておく必要がある，約 100 本の监光ガラスを同時照射し， 小線量より順次加算照射し, 同一ガラスを反㠅使用した. 両端より測定し，両端の值の大きく黑なるものおよび異 常に大きい值を示したものはガラスの傷や污染があるも のと考えて再洗涤し，または点検して傷のあるすのは取 り除いた。Fig. 5 に照射量対レスポンスの関係を示す. レスポンスは上記約 100 本の值の平均值から，同じく全

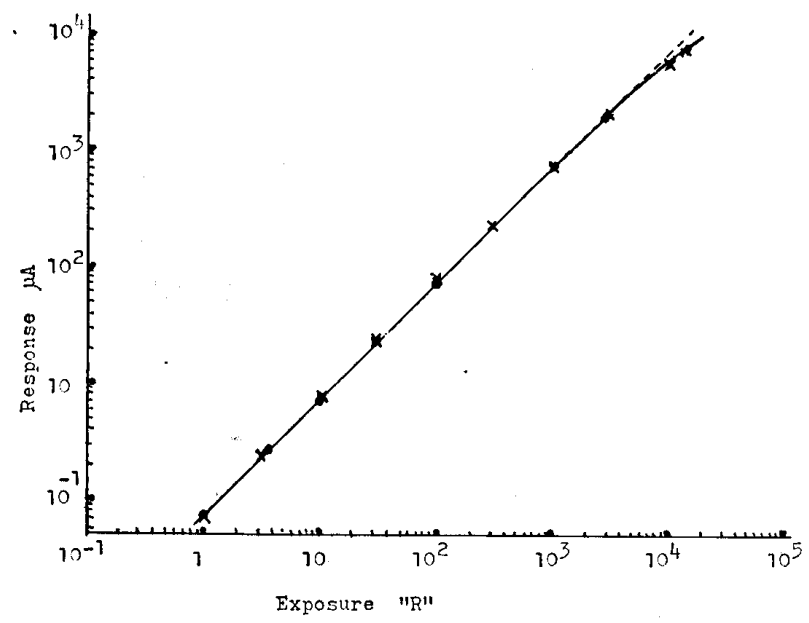

Fig. 5. Relationship of fluoro glass response $(\mu \mathrm{A})$ and exposure ("R"). Fluoro glass : FDR1-1, Fluoro meter : FGD-3B, Exposed by $15 \mathrm{MeV}$ electron beam. back ground 值の平均佔在し引いたものである。ただ し図忛印でホしたものは別に照射した10本のガラスの

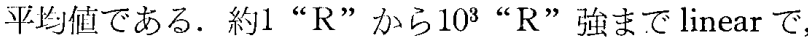
それ以上はやや飽和の傾问を示している。東芝の data によると FD-R1-1 は 1〜 4 $4^{4}$ 亿亘って linear である とされているが17)，乙れよりやや小さい範用となった ことは，照射放射線が極めて鋭いハパルス状のものである ことに関係があるように思われる，直線性を示す範囲に つては同じ FD-R1-1 てつて，荒居は200kV X線 では $3 \times 10^{3} \mathrm{R},{ }^{60} \mathrm{Cor}$ 線では $10^{4} \mathrm{R}$ まで直線性を示した と報告している，そして $200 \mathrm{kV} \mathrm{X}$ 線で低い飽和点を示 したことについては，䖢光ガラスがこの領域で感度が著 しく高いために早く飽和に達するためであろうと論じて (る).

このような飽和点以下では前述の䖺光量計のレンジ切 換に伴う䛊差も含めて linearity は良好である。乙の範 囲で用いる場合， exposure 值に較正する必要があると きはこの範囲内の適当な一つの值の照射をもって較正図 を描くことができる．しかし場合全体としての捛差が大 きくなるから，なるべく多くの標準照射から較正図を作 ることが望ましい.

\section{3. 蛍光ガラスレスポンスの誤差(1)}

前節の測定值を統計的に検討した。乙の場合の「誤差」 には，ガラスのレスポンスのバラツキと前記の蛍光量計 の誤差の双方が含まれる。

ガラス 1 本づつをマークして各個別のレスポンスを追 跡するととは取扱いの煩雑なととから，本実験では行な わなかった，各 exposure に対する蛍光量計の読みの分 布はFig. 6 および Table 4 のようである. Table 4 中 右端の欄は back ground の值のバラツキが, 各exposure におけるレスポンスに与える影響をみる一つの目途とす

Table 4. Distribution of the readings and response of fluoro-glass. (FD-S1-1).

\begin{tabular}{|c|c|c|c|c|c|c|}
\hline \multirow[b]{2}{*}{$\begin{array}{c}\text { Exposure } \\
\text { ("R") }\end{array}$} & \multicolumn{3}{|c|}{ Fluoro-meter readings } & \multicolumn{2}{|c|}{$\begin{array}{l}\text { Response of fluoro-glass } \\
\text { (readings)-(back ground) }\end{array}$} & \multirow[b]{2}{*}{$\sigma_{\text {back }} / \bar{x}_{r}(\%)$} \\
\hline & $\begin{array}{c}\text { Mean } \\
\bar{x}_{m}(\mu \mathrm{A})\end{array}$ & $\begin{array}{c}\text { Standard } \\
\text { deviation } \\
\sigma(\mu \mathrm{A})\end{array}$ & $\begin{array}{l}\text { Relative } \\
\text { standard } \\
\text { deviation } \\
\sigma / \bar{x}_{m}(\%)\end{array}$ & $\begin{array}{c}\text { Mean } \\
\bar{x}_{r}(\mu \mathrm{A})\end{array}$ & $\begin{array}{l}\text { Relative } \\
\text { standard } \\
\text { deviation } \\
\sigma / \bar{x}_{r}(\%)\end{array}$ & \\
\hline $\begin{array}{c}0 \\
\text { (back ground) }\end{array}$ & 0.51 & $\begin{array}{r}0.050 \\
(\sigma \text { back })\end{array}$ & 10.2 & 0 & - & - \\
\hline 0.98 & 1. 20 & 0.0784 & 6.54 & 0.69 & 11. 4 & 7.23 \\
\hline 3.72 & 3.15 & 0.206 & 6.53 & 2.64 & 7.8 & 1.89 \\
\hline 9.67 & 7.41 & 0.298 & 4. 03 & 6.90 & 4.31 & 0.725 \\
\hline 100 & 72.7 & 2.46 & 3.37 & 72.2 & 3.4 & 0.069 \\
\hline 1,000 & 717 & 22.5 & 3. 14 & 717 & 3. 14 & 0.00698 \\
\hline 3,000 & 2,080 & 74.5 & 3.58 & 2,080 & 3.58 & 0.0024 \\
\hline
\end{tabular}



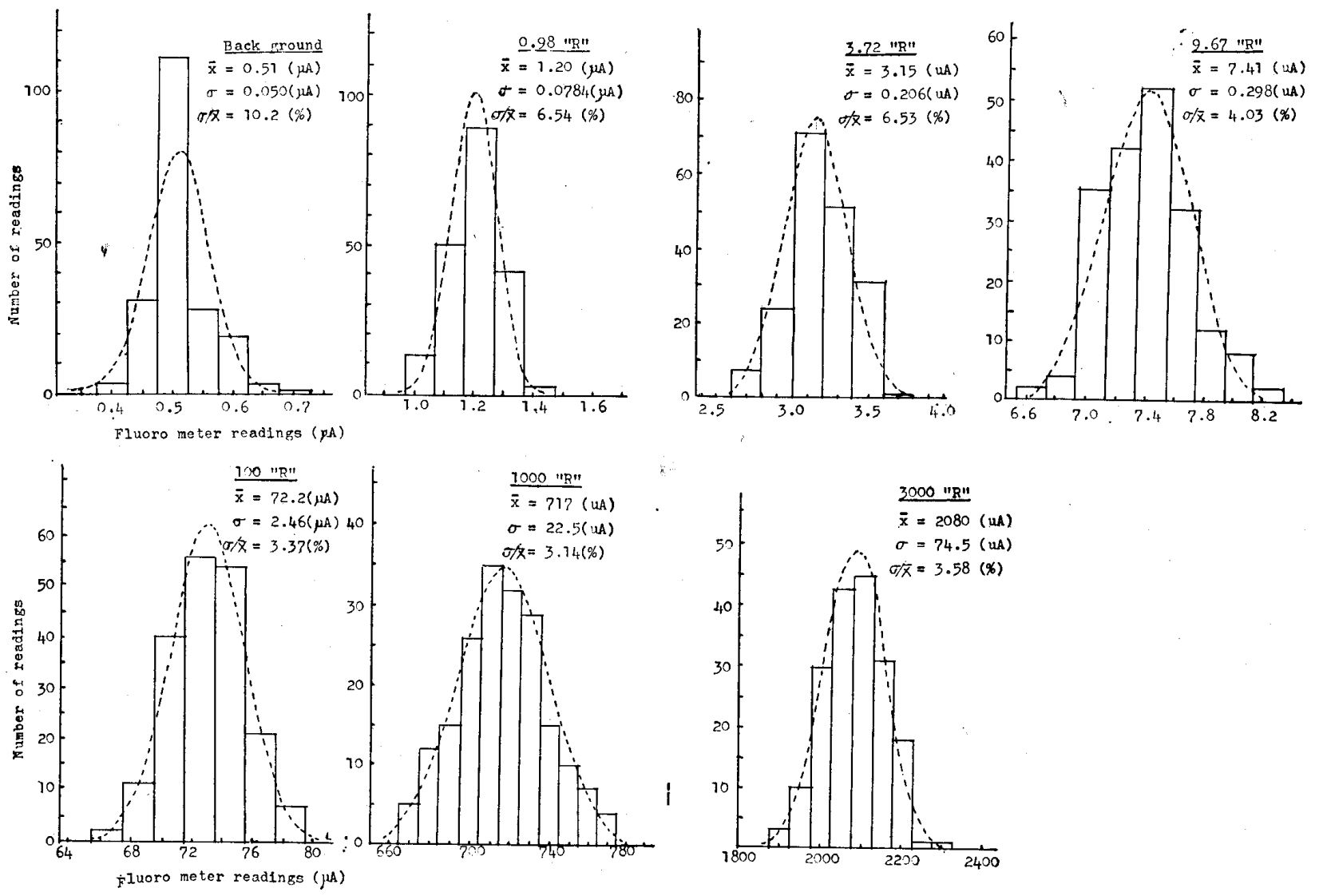

Fig. 6. Distribution of fluoro glass readings (FD-R1-1).

るために求めた值で，この数值が大きいほど back ground の值のバラッキが測定精度に影響することが大きい. しかし，乙れは本実験の上うに back ground の值を平 均值としてそれぞれの照射後の䖺光量から差し引いた場 合についていえるととであって，各国のガラスの back ground を，それぞれの照射後の蛍光量から差し引くよ うにすれば, back groundのバラッキが測定精度に影響 を与えるととはな い. 従って, 本実験 でむとのように各個 の back ground を checkして差し引く ようにしておれば, 特们小 exposure 域 に打ける䛊差は少な くなっていた䈏で ある。

計測值 (蛍光量) はほぼ正規分布を示 す (Fig. 7) が, 巣光 ガラスの污染除去が

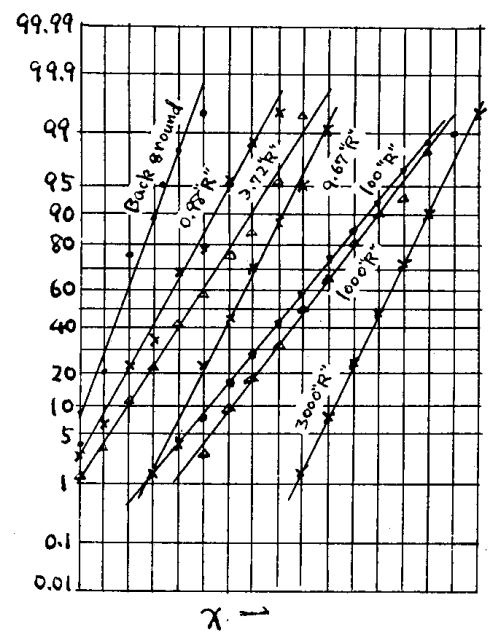

Fig. 7 Distribution test.
十分でないときは特に小 exposure 域に打汀䛊差が大 きく，しかむ(十例㳊偏った分布となる。一例を上げると

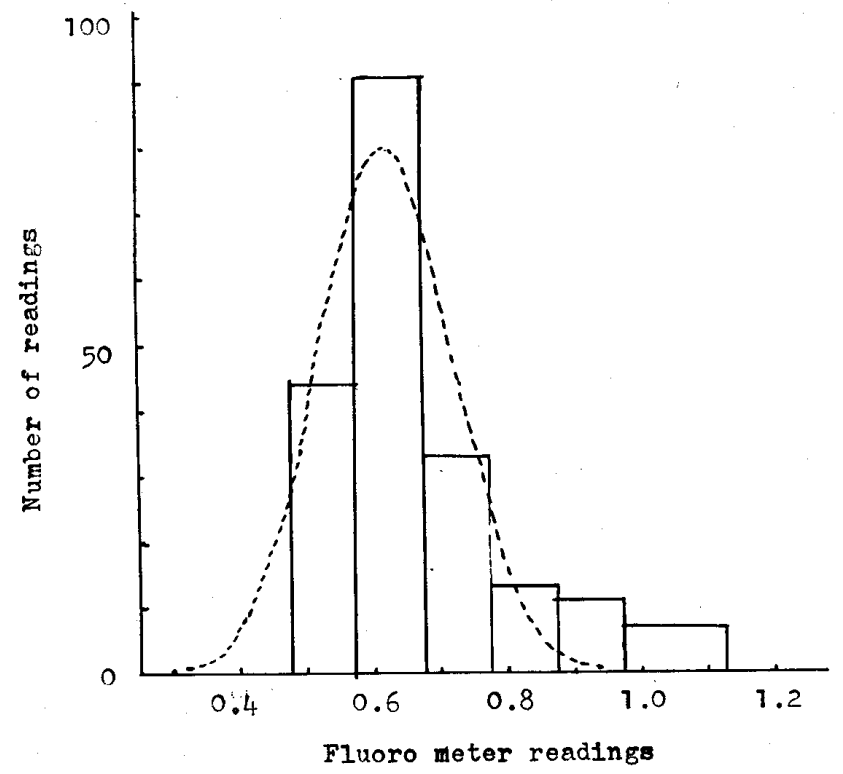

Fig. 8. A case of back grounds of imperfectly cleaned fluoro glasses. (Dotted curve is perfectly cleaned glasses.) 
Fig. 8亿みられるようである。しれは未照射のガラスの 测定值，すなわち back groundであるが，予想上りを の值が大きく，また十側に偏っているため，洗涤が不十 分であることを知り改めて洗った後得た值が先に示した

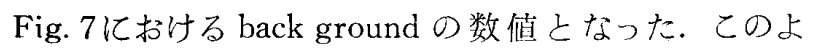
うに特に小線量域での測定にはガラスの励染除去が重要 であって，特に活染の相しいときはク口ム硫酸で洗う。 また，蛍光ガラスは保存中に空気中の水分のため表面が 風化するととがあり，その程度が甚しくないときは，感 度には大きい変化はないが，䛊差範用が大きくなるため， 乾燥容器中に保存する必要がある。

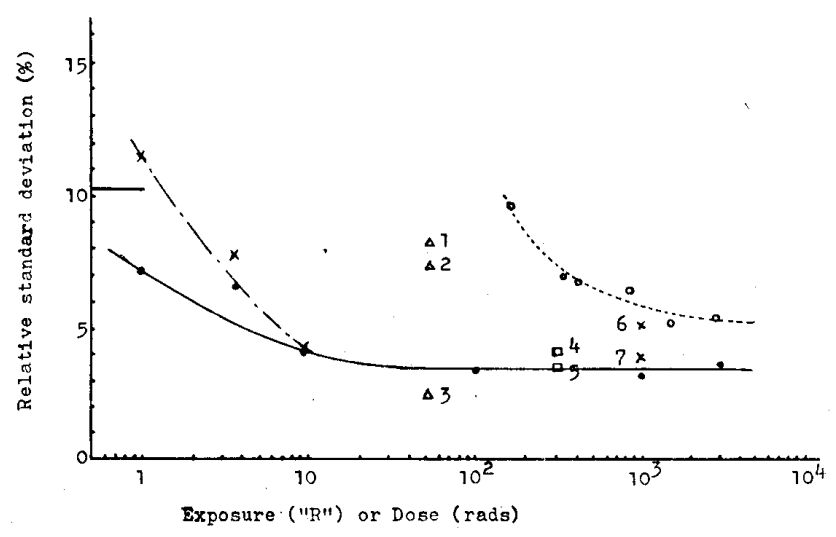

Fig. 9. Relationship of exposure (or dose) and standard deviation.

- Author Readings ( $15 \mathrm{MeV}$ electron beam)

$\cdot-x-\cdot$ Author Response (reading-back ground) (15MeV electron beam)

..o... Hine et al. (2MVp X-ray)-9)

1. Bausch \& Lomb Low-Z glass

2. Bausch \& Lomb High-Z glass

3. Toshiba glass

1-3 : from Yokota-5)

4. Ba glass

5. Li glass

4, 5 : from Arai $\left({ }^{60} \mathrm{Cor}\right.$-ray $\left.)-4\right)$

6. Old type holder

7. New type holder

6,7 : from Yokota et al. -15 )

exposure 值対监光最值またはレスポンスの標準偏差 の関係を図に表わせばFig. 9 のようになる. 比校のた め他の文献にみられるいくつかの值も記入した，著者の dataとしては监光㝵計の読み(いわゆる post-dose) Table 4 亿おける第 4 欄の值とレスポンス (back ground を差 し引いた真の监光量) Table 4 の第 6 欄の值の双方を記 入した著者の data では exposure が大になるに従って 標準偏差は小さくなり，数10“R”で一定(約 $3.4 \%$ ) とな る. Hine の報告9) と比べて著しく良好な値を示してい
る。彼らの報些も約 100 本の同サイズの监光ガラスによ って得たむのであるから，この泪者の相道は监光がラス の筫の違い，および监光量計の所で述べた监光量計の違 いによるむのと考えられる．横田らの data ${ }^{5}$ は測定に使 用した数が不明であるので著者の data と比較するには やや問題があるが，乙れにみられる東芝製と B.L. 社製 のガラスの比較，および荒扂による $\mathrm{Li}$ ガラス40本， $\mathrm{Ba}$ ガラス15本についての值 ${ }^{4)} の$ 比較などを参考にして考え ると，乙れら標準偏差の大きい違にはガラスの質による ところが大きいと考えられる。

先述のごとく, back ground は pre-dose と称し, 照 射後の蛍光量 (post-dose) から差し引くととによって真 の蛍光量 (response) を求めるのであるから, 监光ガラ スの質による，および蛍光量計の構造上の問題として生 じる back groundの大きさの相違は蛍光ガラス線量計 による低線量域での測定に括ける䛊差に特に影響する。

back ground 值は著者の測定ではほぼ 0.7 “ $\mathrm{R}$ に相 当するが, Schulman らは12〜30 R と報告している10)11). また上記 Hine らの報告では 60〜100 rad 相当の範聿の back ground を持つガラスを選んで用いたと記している ところをみると，更に大きい back ground をつつガラ スもかなりあるものと想像される. Cheka は B.L. 社の Micro-dosimeter reader の初期の形式のものに多少の 改良を加えた巣光量計による data を発表しているが3), これによると original gass (high-Z) について back ground は 18〜20R 相当であり, Schulman の low-Z glass は back ground はほぼ同じで感度がやや高く，東 芝の横田らの開発したToshiba П なるガラスでは感度 は約 2 倍, back ground が〜 $5 \mathrm{R}$ 相当であったという.

Toshiba II ガラスは著者の用いたものと同じであるが， その bock ground が著者の data 約 0.7 “ $\mathrm{R}$ ” に対して5 $\mathrm{R}$ と大きい値を示すのは, 巣光量計の構造の相異による

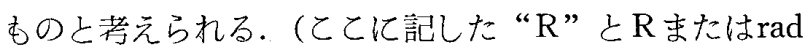
の関係についてはほぼ同等と考え得るととは既に示し た.）Hine らのごとく絶対值，熘差範囲ともに大きい back gronud を，著者の本実験のごとく全体の平均值 を求めて照射後の緹光量 (post-dose) から差し引くなら ば，感度のバラッキ以外に back groundのバラッキ (<士20rad ) の影響が入る. したがって彼らの测定系で は最小測定可能值は恐らく数10 rad であろう。これに対 し著者の用いたFGD-3B と FD-R1-1の組合わせでは1 $R$ でむ測定可能範罒で, back ground を個別に差し引く ようにすればその䛊差篹团は更に小さくするととができ よう. 数 R以上の測定に際しては back ground は平均 
值を用いれば十分であり，約 $100 R$ 以上の测运ではBack ground の存在を無視し得る.

これらの結果が高エネルギX線， $\boldsymbol{\gamma}$ 線にも適用し得る ことは再三記したが, $200 \mathrm{kV}$ 程度のX線については感度 が大きくなるため back ground の影響は更に少なく， 従って最小測定可能值および品差は小さくなるであろう.

更に横田らはホルダーを改良するととによって感度を 大きくし，䛇差を小さくし得たととを報告している15). (Fig. 11)

\section{4, 蛍光ガラスレスポンスの誤差 (2)}

1 つの測定に用いる蛍光ガラスの数によってあ標準偏 差が異なることは当然で，乙れについては本学産婦人科 教室浜崎が $15 \mathrm{MeV}$ X線 100 “R”照射について Fig. 10 のごとく報告している゙12.すすなお 1 本単独で用いた場 合の $\sigma / \bar{x}$ は約 $7 \%, 2$ 本を用いれば $5 \% ， 3$ 本で約 $4 \%$,

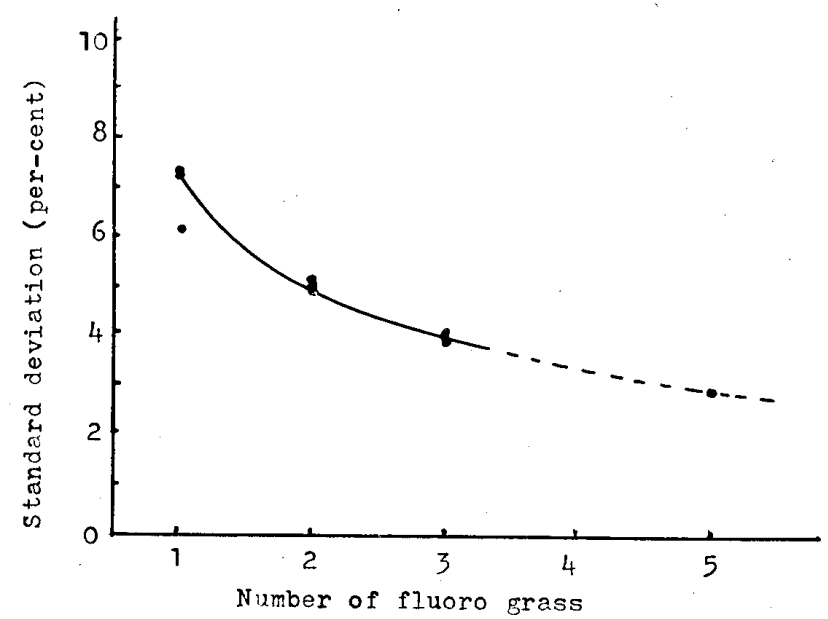

Fig. 10. Relationship of standard deviation and number of fluoro glass.

(from Hamasaki 12)

5 本同時に用いると約 $3 \%$ の値を示している．従って䖝 光ガラスによる測定に際しては 1 点につき数本の监光ガ ラスを用いなければ精度を上げるととはできない。ただ し深部線量分布測定のように連続した多数点の測定をす るときは個々の誤差は smoothing されるから各点 1 本 づつでむよい．著者はとのような場合重要な部分だけ複 数本のガラスを用いるようにしている.

また，先に少し触れた営光ガラスの温度特性も誤差原 因となり得る。乙の点についておいくつかの報告がある が144)12), 浜崎の前記文献には次のように記されてい る.

「放射線照射時の単光ガラスの温度特性はFig. 11 にみ られるように，温度によって感度が異なり，人体内に単 光ガラスを埋めて用いるような場合は $+0.26 \% /{ }^{\circ} \mathrm{C}$ であ

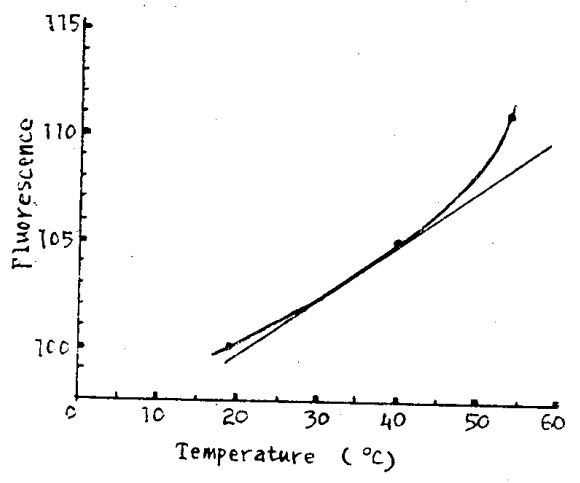

Fig. 11. Dependency of temperature.

り,また人体体温 $\left(37^{\circ} \mathrm{C}\right)$ と室温 $\left(20^{\circ} \mathrm{C}\right)$ では約 $5 \%$ 感度の 相異がある．また，放射線照射後监光ガラスを加熱する 之蛍光量が増加する．例として, 照射後の蛍光ガラスを $100^{\circ} \mathrm{C}$ で 10 分間処理をするととによって $25 \%$ の蛍光量の 增加を認めた。しかし, 照射前のガラスの加熱処理(100 ㄷ)は殆んど感度に影響なく，また back ground の大き さむ変化しない. 従って照射前に蛍光ガラスを加熱滅菌 するととむ可能である」

以上は著者と同じ巣光ガラス, 巣光量計を用いて得た 成績であるが，他の報告をみると横田らが55 C以下で+ $0.2 \% /$ C の温度依存性を示したという（ガラスは同種の あの).とれらの点から注意せねばならないととは，照 射時の温度が標準照射の温度と異なる場合，例えば人体 内に埋めて照射したすのを室温で標準照射したガラスに よる較正図で線量值に換算する場合については温度特性 の補正を必要とすること，照射後のガラスを高温にしな いととの 2 点である.

\section{Fading}

先の実験に用いたがガラスを室温乾燥容器内に保存, 最終照射日から約 100 日後に蛍光量の測定を行なった。 その結果蛍光量の全平均値は約 $5 \%$ fading 走示し, そ の標準偏差は初期測定時において $3,58 \%$ あ゙ったものが, $5.7 \%$ 增加した。文献によると, 横田らは東芝 FD-P8 なるガラスについて 13 週間に $3 \%$, Schulman ガラスで 6\%の fading があったと報告しておりり，Barr らは1カ 月に約 6\%13)，荒居は 150 日で約10\%，300日で約20\%の の fading を出, Hodara は100日間に40\%の fading を報 告している ${ }^{14)}$ 。乙れらの報告からみて, fading につい てあ東芝ガラスの方が優位にあるようである。 バラッキ が大きくなるととについては荒居の報告にあ見られるが， てれら fading の速さが個々のガラスによって異なるた めであると考えられる。

または，照射後の蛍光ガラスの蛍光測定を何度す繰返 
すと除々に䖝光量か娍少する。更に，羊続して盗光星測

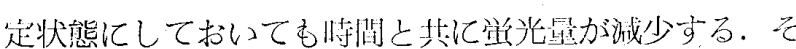
の状沉は Fig. 12 の上うである. 緤返し測定の壦合，ガ ラスの傷は最後に顕微鏡で確かめ全く認められなかった から，傷が原因でないととは明らかで，また蛍光量計の drift は照合ガラスで調整したから，乙れむ考えられな い. 連続測定では測定開始前, 終了直後に照合ガラスで check し感度変化は無視し得る程度であった。従ってこ の現像は明らかに蛍光の fading と考えざるを得ない.

紫外線照射による巣光核の破壞によるものであろうが， 断続して照射した方が連続の場合より fading が大きい のは何故だろうか. 1 回の蛍光測定に必要な時間は 10 秒 以下であるから100回の測定では15分足らずの紫外線照 射時間の等であるにもかかわらず，fading が大きい結 果となっている。乙の現象については文献にはみられな
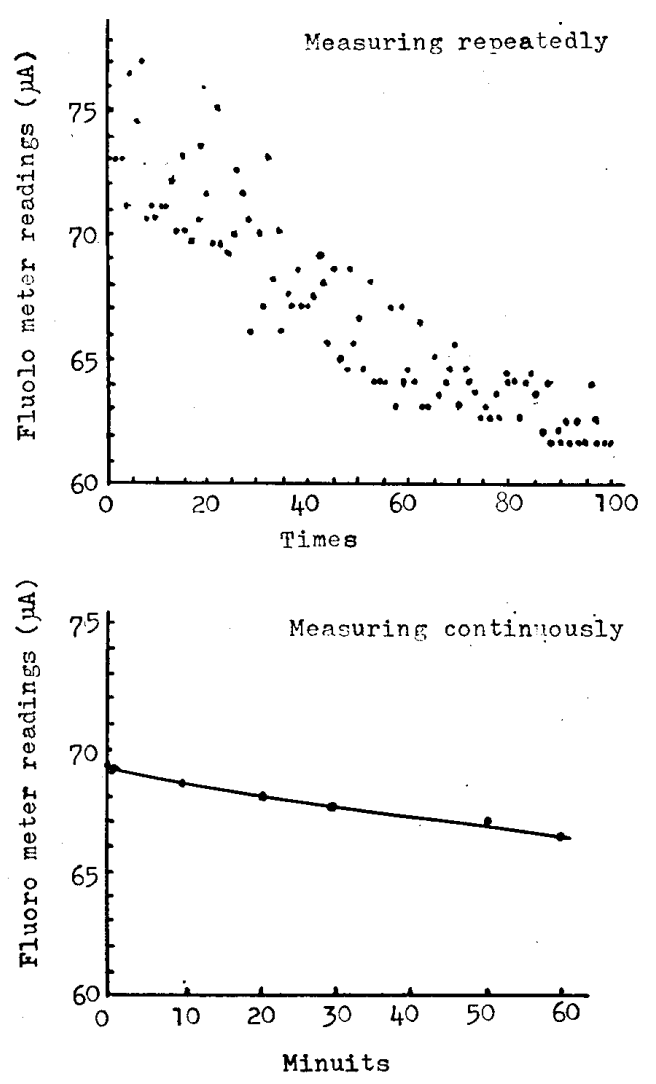

Fig. 12. Fluorescence fading by measuring.

いので，更に実験検討を続けるつもりである。しかし， 実用上，1つのガラスの蛍光測定は数回以内で終るから この現象が蛍光ガラスによる線量測定に及ぼす影響につ いては一般に考慮する必要はない。

\section{VI. 総括}

蛍光ガラス線量計による測定值の誤差について 巣光ガラスは東芝製FD-R1-1，监光量は東芝製FGD 3B を用いて実駼検剑を加えた。照射放射線はべータト ロン $15 \mathrm{MeV}$ 電子線である。

\section{蛍光量計について}

巣光量計は最大感度にした場合， \pm 0.15 “ $R$ ” 程後相 当の変動がある. 主として機械的なが夕によると思われ る㖣差は約 100 “ $\mathrm{R}$ ” の測定時に， $\sigma / \bar{x}=1.56 \%$ 程度であ つた。

\section{蛍光ガラスレスポンスについて}

$15 \mathrm{MeV}$ 霆子線汇対してほぼ 1 103 “R” に豆ってよ い linearity を示した。他の data 亿みられる $10^{4} \mathrm{R}$ まで の linearity を示さなかったのは照射した電子線が極め て鋭いパルス状のものであることに関係があるかす知れ ない.

back groun は約 $0.7 \pm 0.07$ “R” $(\sigma / \bar{x} \div 10 \%)$ であっ て，同じ蛍光ガラスを用いた Cheka の data と比べて 一桁低い值を示す。乙扎は蛍光量計の構造の相異汇よる むのであろう。ガラスのみの比較でも東芝ガラスは Schulman ガラスよりかなりよい性能を示す。

监光量計の読み，执よび监光ガラスレスポンスにつ てその值を喻討すると，1“R”の照射でレスポンスは 11.4\%の標準偏差を示し，4 “R” で約8\%，10 “R” で 約4,3\%，100 “R” で約3,4\%の標準偏差を示し，ての值 で飽和する. back ground を個別差し引くようにすれ ば少ない照射に対してのバラッキはこの值上り減少する であろう。

蛍光ガラスによる最小測定可能值は約 1 “R” と考え られる，乙の值は外国文献に比へて著しく良好である。

著者のこれらの実験值は他の放射線にも適用でき“R” はRまたは $\mathrm{rad}$ 之荒い近似で同一と考元てよい. $200 \mathrm{kV}$ 程度のエネルギX線に対しては感度の相異から上記より ややよい性能を示すであろう。

浜崎の報告から，同時に数本の蛍光ガラスを用いると とが適当と考えられ，また温度特性む考虑する必要があ 万。

\section{蛍光の fading}

長時間保存のため生じる fading 以外に蛍光量測定時 の励起紫外線によると思われる fading 亿も一応注意を する必要がある，長時間保存による fading は100日間に 5\%の值を得たが，バラツキが大きくなる。乙れは個々 のガラスにより tading の速さが買なるためと思われる。 
以上から，坚光量計 FGD-3B (東芝) を用い，监光が ラス FD-R1-1（東芦）によって線量测定を行なう場合， ガラスなどの污染除去, 温度特性, fading などを十分考 虑し，同時に 3 本以上の监光ガラスを用い, 約 $100 \mathrm{R}$ 以 上を测定するようにすれば，その栖準偏差は3〜 4\%程废 である。また最小測定可能範囲は，約10\%の標準翛差を 許すならば $1 \mathrm{R}$, back ground 老個別汇測定差し引くよ うにするならば標準偏差は下げ得るであろう。

紧光ガラス線量計は，長時問に亘って物理的にも化学 的にも比較的安定であるとと，積算できること，その体 皘が椣めて小さいこと，広い線量域に亘る直線性をもつ ことなどの利点があり，いくつかの点，制約があるに せよ非常に便利かつ有能な線輻計であるといえよう。

\section{謝辞}

本研究に終始御助言，御指導を賜わった本教室滕野守 次教授に感謝致します。また種々御便”突を賜わり，適切 な御助載いた東誌中央研究所横田食助博士および同 研究室の方々，更に然験を手伝って戴いた伊滕敬三技的， その他の方々に感謝致します。

(本研究要旨は第21回日放技学会総会一1965年, 東京一 で解告した.)

\section{参考 交 献}

1）横田良助他：東茫レビュ一，17，1，65-71（1962）。

2) YOKO'TA, R., NAKAJIMA, S. : Health Phys., 5, 219-224 (1961).

3) CHEKA, S. S. : Health Phys., 8, 551-554 (1962).

4）荒居龍雄：日医放学会誌，23，6，753-772 (1963).

5）横田良助他：会議参考資料（1961）.

6) CHEKA, S. S. : Health Phys., 10, 303-314 (1964).

7) 東㘳 FGD-3B 使用説明書

8) Bausch \& Lomb Optical Co. : The New Bausch \& Lomb Microdosimeter System.

9) HINE, G. J. et. al. : Radiology, 78, 1, 44-(1962).

10) SCHULMAN, J.H., et al : J. App. Pyhs., 22, 12, 1479 1487 (1951).

11) SCHLMAN, J. H., et al. : Nucleonics, 11, 10, 5256(1953).

12）浜崎䆓：産婦人科の進步，18，2，1-17 (1966).

13) BARR, N. F. et al. : Health Phys., 7, 48-53 (1961).

14) HODARA, M., et al. : Radiology, 73, 11, 693706 (1959).

15）横田良助他：会議参教資料 (1963). 